\title{
РАННИЕ СЛАВЯНЕ В ПОВЕСТИ ВРЕМЕННЫХ ЛЕТ МИФЫ ЛЕТОПИСЦЕВ И ИСТОРИОГРАФИИ
}

\author{
EARLY SLAVS IN THE PRIMARY CHRONICLE. \\ MYTHS OF THE CHRONICLERS AND HISTORIOGRAPHY
}

\begin{abstract}
The author of the Primary Chronicle (PC) had a dual purpose of proving the legitimacy of the dynasty of Scandinavian origin and recording the traditions of the ethnic Scandinavian and Slavic populations. The author of this paper endeavours to analyse the authenticity of information provided in the PC concerning the origin of early Slavs. Before a critical method of studying medieval narrative texts was developed in the late $19^{\text {th }}$ and the early $20^{\text {th }}$ century, the authenticity of medieval chronicles had not been questioned. Therefore, the $19^{\text {th }}$ century historiography treated all the information from medieval texts as authentic. In Russian historiography it was A.A. Shakhmatov who while dealing with the PC, laid down the foundations of the critical method in dealing with chronicles. He was the founder of the famous school of historical philology which has placed text analysis at its centre. Despite this approach, a "new hypothesis" appeared in the last decades of the $20^{\text {th }}$ century (see the linguistic theory of O.N. Trubachev) gained wide publicity both in Russia and abroad. Trubachev's theory did not take into conssideration the results of either text analysis or the findings of archaeology and was a return to the position from the $19^{\text {th }}$ century. The author of the paper shows that this theory was a blind alley.
\end{abstract}

Keywords: origin of Slavs, Primary Chronicle, authenticity of chronicletexts, critical method

В составленной в начале XII-ого века Повести временных лет рассказывается о происхождении славян в соответствии с преданиям своего времени. Однако, исходя из структуры летописи можно установить некоторые факторы, повлиявшие на восприятие летописцем устных преданий и свидетельствующие о его компиляторской деятельности.

В историографии во время открытия древних текстов и на протяжении XIX-ого века не сомневались в достоверности переданных информаций. Однако, XIX-й век является и эпохой национального самосознания, частью

* ORCID: 0000-0001-5612-0261; University of Pécs / Hungary, Faculty of Humanities, Institute of History, Department of Medieval and Early Modern History, 7624 Pécs, Rókus u. 2., font.marta@ pte.hu. 
которого стали и элементы летописного материала. Несмотря на то, что А.А. Шахматов выработал метод критического подхода к летописям уже к началу XX-ого века, в историографии только с трудом преодолевается средневековый подход: безусловная вера в истину написанных вещей. К этому относится и рассказ о происхождении славян.

\section{РАННИЕ СЛАВЯНЕ В ЛАТЫНОЯЗЫЧНЫХ ХРОНИКАХ СЛАВЯНСКИХ СТРАН НАЧАЛА ХІІ В.}

В средневековой историографии - как в летописях, так и в латыноязычных хрониках - является одним из важнейших аспектов описание начала своего рода (origo gentis; Kersken 1995), и тем самым указание на его место среди христианских народов. В Средней и Восточной Европе первые хронисты / летописцы в начале XII века были создателями первых нарратив, по всей вероятности, они пользовались лишь некоторыми записями местных монастырей. В этом плане их знания о более ранних событиях составляли отчасти произведения, созданные на чужих землях, отчасти местные предания (как современное oral history). В первых произведениях все это дополнялось и комбинировалось с объяснениями хронистов / летописцев. В Средней и Восточной Европе почти одновременно, в начале XII века создавались первые нарративы о начале происхождения династий и о прошлых событиях (Kersken 1995, 822-827; Font 2003): Chronica Boemorum Козьмы Пражского в Чехии (Cosmas Pragensis 1995), Chronicae et gesta ducum et principum Polonorum Анонима Галла в Польше (Gallus Anonymus 1952) и Повесть временных лет (ПВЛ) на Руси (ПВЛ 1950; венгерский перевод: Régmúlt idők elbeszélése 2015). Даже сюда можно отнести из неславянского соседства какой-то вариант венгерской хроники, написанный при дворе Коломана Книжного (Kristó 2002, 32-36; Thoroczkay 2016, 110). Среди авторов перечисленных произведений известен лишь Козьма Пражский. О безымянном авторе польской хроники можно установить, что он был единственным создателем текста хроники, но откуда он попал в Польшу - о том все еще идут дискуссии (Bagi 2007, 8-17). На самом деле ПВЛ не дошла до нас как самостоятельное произведение, нам известно как часть Лаврентьевской летописи 1377 г. (ПСРЛ т. І.) Благодаря успешной реконструкции Шахматова текст ПВЛ считается отдельным произведением, независимым от контекста различных кодексов (Шахматов 1916; ПВЛ 1950). Однако, структура текста и возможные предыдущие своды оспоримы и в наши дни.

В хрониках, возникших в славянских странах не одинаково упоминается общее славянское прошлое. Исходным пунктом повествования о происхождении своего общества является библейский рассказ о Ное, от кого произошли все народы. Общим аспектом трех хроник можно считать, что в центре рассказа 
ставится история правящей династии. А по отношению к истории ранних славян тексты не одинаковы. Козьма Пражский с самого начала пишет о своем народе, ранние славяне в общем не упоминаются. Например „Igitur huius narrationis sumpsi exordium a primis incolis terre Boemorum..." и сразу же приступает к рассказу о династии: „Continet autem hic liber Boemorum gesta, prout mihi scire licuit, digesta usque ad tempora primi Bracizlai, filii Odalrici” (Cosmas Pragensis 3). В прологе хроники Анонима Галла пишется подробно о том, какими странами граничит Польша. „Igitur ab aquilone Polonia septemtrionalis pars est Sclauonie, que habet ab oriente Rusciam, ab austro Vngariam, a subsolano Morauiam et Bohemiam, ab occidente Daciam aet Saxoniam collaterales" (Gallus Anonymus 6-7). Территория «Sclauonia» интерпретается по-разному: или обозначает всю территорию, где жили славяне; или территорию западных славян. Более вероятно «Sclauonia» обозначала территорию по восточной границе Священной римской империи (Bagi 2012, 58). За географическим описанием он так продолжает: „Sed ne digressionem nimium prolixam fecisse videamur, ad intentionis nostre propositum revertamur. Est autem intentio nostra de Polonia et duce principaliter Bolezlao describere eiusque gratia quedam gesta predessorum digna memoria recitare.” (Gallus Anonymus 9). В отличие от чешской и польской хроник в ПВЛ говорится о всех славянах, хотя первые слова указывают на территорию: „откуда есть пошла Русская земля” (ПВЛ 1950, I. 9; Régmúlt idők elbeszélése, 15). История территории Руси и славянского народа в ПВЛ рассказывается в начале летописи более обширно, чем в двух латыноязычных хрониках, по-нашему потому, что на Руси правящая династия произошла не из славянской среды.

Короткое сопоставление трех хроник

\begin{tabular}{|c|c|c|c|}
\hline Особенность & Козьма Пражский & Аноним Галл & Составитель ПВЛ (Сильвестр) \\
\hline заглавие & Chronica Boemorum & $\begin{array}{c}\text { Chronicae et gesta } \\
\text { ducum sive principum } \\
\text { Polonorum }\end{array}$ & Повесть временных лет \\
\hline время написания & 1110-ые гг. & ок. 1113-1115 гг. & редакции: 1113, 1116, 1118 гг. \\
\hline структура & книги I-III и приложение & пролог и книги I-III & $\begin{array}{c}\text { компиляция летописного } \\
\text { характера }\end{array}$ \\
\hline цель автора & $\begin{array}{c}\text { происхождение и начало } \\
\text { династии Пшемыслей }\end{array}$ & $\begin{array}{c}\text { происхождение } \\
\text { и начало династии } \\
\text { Пьястов }\end{array}$ & $\begin{array}{c}\text { откуда есть пошла Русская } \\
\text { земля и история династии } \\
\text { Рюриков }\end{array}$ \\
\hline \multirow[t]{2}{*}{ история династии } & \multicolumn{3}{|c|}{ поддержка легитимации современного автору правителя } \\
\hline & \multicolumn{2}{|c|}{ основная задача } & уловимо в подсексте \\
\hline известия о славянах & $\begin{array}{c}\text { название «славяне» } \\
\text { в общем не упоминается. }\end{array}$ & $\begin{array}{c}\text { описание территории } \\
\text { «Sclauinia» }\end{array}$ & $\begin{array}{c}\text { подробно о славянах } \\
\text { (не только о восточных) }\end{array}$ \\
\hline мифы & \multicolumn{3}{|c|}{ „oral history” } \\
\hline
\end{tabular}


Независимо от истории правящей династии славянское прошлое как общая история славян описывается лишь в ПВЛ, и при этом упоминаются не только восточные славяне. Первые информации находятся в недатированном Введении, потом в рассказах периода 852-900 гг. Для обеих частей характерны заимствования из византийских хроник и вставления из библейских рассказов с дополнениями из местной мифологии и собственных опыт автора.

Текст недатированной части тематически разделяется по следующему: (цифры обозначают количество компютерных единиц на основе венгерского перевода, с помощью которых выражается объем текста)

\begin{tabular}{|c|c|c|c|c|c|}
\hline Пч. & Рассказ & $\begin{array}{l}\text { Объем } \\
\text { текста }\end{array}$ & Пч. & Рассказ & $\begin{array}{l}\text { Объем } \\
\text { текста }\end{array}$ \\
\hline 1. & $\begin{array}{c}\text { «Откуда есть пошла русская } \\
\text { земля»? }\end{array}$ & 171 & 9. & $\begin{array}{c}\text { миссионерская деятельность } \\
\text { апостола Андрея в Киеве }\end{array}$ & 1347 \\
\hline 2. & $\begin{array}{c}\text { всемирный потоп и потомство } \\
\text { сыновей Ноя }\end{array}$ & 1399 & 10. & $\begin{array}{c}\text { мифологическое произхождение } \\
\text { восточных славян и города } \\
\text { Киева }\end{array}$ & 1391 \\
\hline 3. & $\begin{array}{c}\text { дополнения местными } \\
\text { племенными преданиями }\end{array}$ & 876 & 11. & $\begin{array}{c}\text { дунайские славяне и кочевые } \\
\text { народы (обры) }\end{array}$ & 1121 \\
\hline 4. & Вавилонское столпотворение & 976 & 12. & $\begin{array}{c}\text { перечисление племен западных } \\
\text { славян }\end{array}$ & 1058 \\
\hline 5. & $\begin{array}{c}\text { дополнения о происхождении } \\
\text { славян от Ноя }\end{array}$ & 75 & 13. & $\begin{array}{c}\text { разные обычаи племен } \\
\text { восточных славян }\end{array}$ & 1306 \\
\hline 6. & поселение славян на Дунае & 687 & 14. & размышление о роли прав & 1786 \\
\hline 7. & поселение славян на Днепре & 645 & 15. & $\begin{array}{c}\text { обычаи кочевых народов } \\
\text { (хазары, печенеги, половцы) }\end{array}$ & 427 \\
\hline 8. & водный путь «из варяг в греки» & 1103 & 16. & налоги хазарам & 1188 \\
\hline
\end{tabular}

В Вводной части ПВЛ недостаток информаций дополняется путем заимствований из византийской церковной и светской литературы (нпр. Georgios Hamartolas см. Истрин 1971; Ioannes Malalas см. Истрин 1994; Georgios Continuatus, Breviarium Patriarch Nikephoros, Theophylaktos Simokattes, см. Balogh 2015, 284-289; Вилкул 2019; об общем культурном влиянии Византии см. Avenarius 2000, 177-211). 
По происхождению текста (Font 2010, 318)

\begin{tabular}{|c|c|c|c|c|}
\hline \multicolumn{2}{|c|}{ Основы информаций } & Объем & $\begin{array}{c}\text { Цифры высшей } \\
\text { таблицы }\end{array}$ & $\%$ \\
\hline \multirow{2}{*}{ заимствования } & из Библии & 2375 & 2,4 & 15 \\
\cline { 2 - 5 } & из византийских хроник & 4254 & $9,11,14$ & 27 \\
\cline { 2 - 5 } & из житий святых & 687 & 6 & 50 \\
\hline \multirow{2}{*}{$\begin{array}{c}\text { традиции / мифы } \\
\text { собственный опыт авторов (слово «нынъ» указывает на } \\
\text { современное автору время) }\end{array}$} & 4813 & $1,3,5,7,8,10,12,13$, & 3 \\
\hline \multicolumn{2}{|c|}{ вместе } & 15556 & 15 & 100 \\
\hline
\end{tabular}

В недатированной вводной части пишется о славянах на двух местах:

(1) «Спустя много времени сели славяне по Дунаю, где теперь земля

Венгерская и Болгарская. От тех славян разошлись славяне по земле и прозвались именами своими от мест, на которых сели. Так одни, придя, сели на реке именем Морава и прозвались морава, а другие назвались чехи. А вот еще те же славяне: белые хорваты, и сербы, и хорутане. Когда волохи напали на славян дунайских, и поселились среди них, и притесняли их, то славяне эти пришли и сели на Висле и прозвались ляхами, а от тех ляхов пошли поляки, другие ляхи - лутичи, иные - мазовшане, иные поморяне. Также и эти славяне пришли и сели по Днепру и назвались полянами, а другие - древлянами, потому что сели в лесах, а еще другие сели между Припятью и Двиною и назвались дреговичами, иные сели по Двине и назвались полочанами, по речке, впадающей в Двину, по имени Полота, от нее и получили название полочане. Те же славяне, которые сели около озера Ильменя, прозвались своим именем - славянами, и построили город, и назвали его Новгородом. А другие сели по Десне, и по Сейму, и по Суле, и назвались северянами. И так разошелся славянский народ, а по его имени и грамота назвалась «славянская» (ПВЛ 1950, I. 10-11; Régmúlt idők elbeszélése, 19-20).

(2) «Когда же славяне, как мы уже говорили, жили на Дунае, пришли от скифов, то есть от хазар, так называемые болгары, и сели по Дунаю, и были насильники славянам. Затем пришли белые угры и наследовали землю Славянскую» (ПВЛ 1950, I. 14; Régmúlt idők elbeszélése, 23-24).

В дальнейшем о ранних славянах говорится в ПВЛ под 852-899 гг. Однако, для характеристики текста целесообразно расширить анализ до 970 г. С последней третьи X в. летописные рассказы безусловно сосредоточатся на истории Руси и правящей династии. Рассказы периода 900-970 гг. являются 

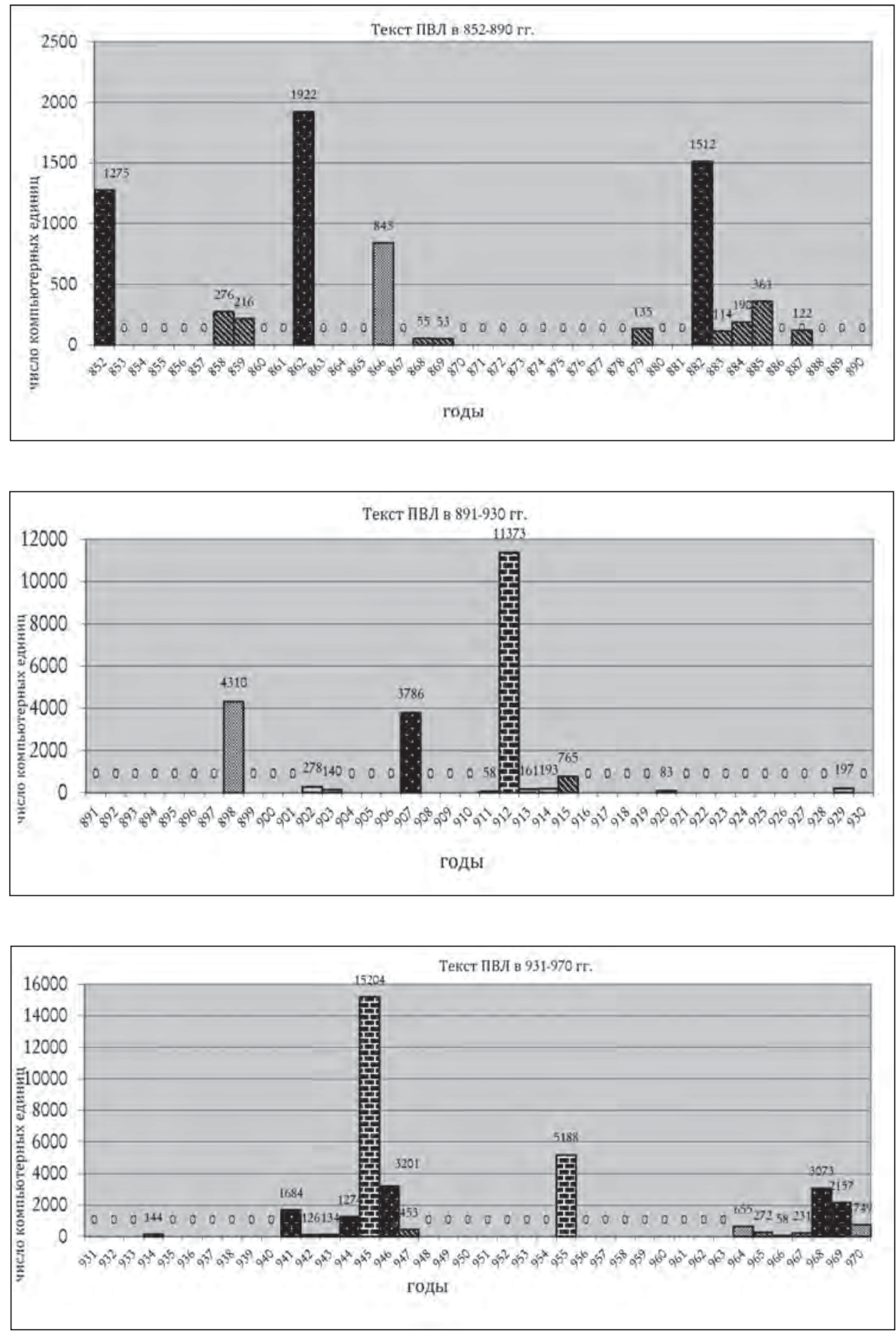
смешением скандинавских традиций и заимствований из византийских хроник. В тексте периода 852-970 гг. отмечено 119 лет, из которых к 37 году добавлены рассказы, в остальных 82 случаях указан лишь год без информаций. Из 37 лишь 12 раз превышает объем рассказов 1000 компютерных единиц (Font 2015, 262-264). Наверно летописцу было нечего рассказать (см. графики выше).

В период 852-970 гг. о славянах упоминается три раза. Впервые в связи с налогами, которого требовали хазары (859 г.), потом в рассказе о призвании варяг (862 г.); обе истории относятся исключительно к восточным славянам. О славянах, живуших на Дунае упоминается под 898 г.

«В год 6406 (898). Шли угры мимо Киева горою, которая прозывается теперь Угорской, пришли к Днепру, и стали вежами: ходили они так же, как теперь половцы. И придя с востока, устремились через великие горы, которые прозвались Угорскими горами, и стали завоевывать живших там волохов и славян. Сидели ведь тут прежде славяне, а затем Славянскую землю захватили волохи. А после угры прогнали волохов, унаследовали ту землю и поселились со славянами, покорив их себе; и с тех пор прозвалась земля Угорской. ... Для них ведь, моравов, первоначально созданы буквы, названные славянской грамотой; эта же грамота и у русских, и у болгар дунайских» (ПВЛ 1950, I. 20; Régmúlt idők elbeszélése, 34-35).

За цитированной частью следует жизнеописание Константина-Кирилла и Мефодия (ПВЛ 1950, I. 20.; Régmúlt idök elbeszélése, 36-38), которое составляет большую часть рассказа 898 г. (4310 компютерных единиц) Этот текст не совпадает ни с одним дошедшим до нас житием, поэтому Лихачев считает, что летописец ПВЛ пользовался недошедшим, незнакомым текстом (ПВЛ 1950, II, 257-258). А вставление жития под 898 г. ошибочно с точки зрения и жизни Константинва-Кирилла (826/827-869), и Мефодия (сса. 815-885). Их имена тесно связаны с византийской миссией среди моравы (Obolensky 1999, 96-98, 180-186; Н. Tóth 2003), а их ученики (Климент, Наум и Ангелий) играли важную роль в организации болгарской церкви (Avenarius 2000, 150-176; H. Tóth 2003). Племя морава получило название от реки Моравы (она впадает в Дунай), по которой они жили, а болгары жили по нижнему течению Дуная. Авторитет святых, создавших славянский альфавит, привел к тому, что летописец связывал с их именами прародину славян. Не надо объяснить значение письменности с точки зрения летописца. Неслучайно, он пишет об этом на разных местах, но информация основывается на том же источнике (ПВЛ 1950, II, 257; Régmúlt idők elbeszélése 35. сноски 106 и 108). В литературе о ПВЛ уже давно известное и принятое установление, согласно которому житие Константина-Кирилла и Мефодия втавлено в текст из какого-то письменного источника. 


\section{ОТКРЫТИЕ ЯЗЫКОЗНАНИЯ?}

С 1980-ых гг. Олегом Трубачевым (1930-2002) было сформулировано мнение о том, что прародина славян была расположена в Карпатском бассейне (Трубачев 1982-1985). Идея Трубачева поднялась с того, что среди географических названий Карпатского бассейна - в первую очередь поселений и вод - находятся в значительном количестве названия славянского происхождения. Это явление уже неоднократно было изучено венгерскими языковедами и были сделаны попытки установить с какого из славянских языков эти названия берут свое начало (Kniezsa 1938, 399-433). Исследователи не разу пришли к тому, что нередкий случай, когда одно и то же название можно объяснить как заимствование из разных славянских языков. Конечно, появились и разные гипотезы (Kniezsa 1938, 399-433; Moór 1930; Melich 1925-1929). Однако, дальнейшей сложностью является датировка возникновения географических названий, ведь их первое упоминание в источниках совсем случайно. Несмотря на это появились результаты в том аспекте, что какие из названий сформировались до обретения венграми родины в Карпатском бассейне, а какие после этого. Много названий появилось на протяжении XIII-XIV вв. благодаря переселенцам того времени из славянских стран (см. Font 2013, 29-38).

Однако, Трубачевым недостаточной четкостью были использованы географические названия Карпатского бассейна. Без особой аргументации он высказал, что все названия рек и вод надо считать безусловно ранними до появления венгров в этом регионе. Для русского языковеда доказательством послужил рассказ ПВЛ о славянах: история о славянах на Дунае в вводной части и их упоминание в связи с появлением венгров около Киева. Трубачев предположил, что упомянутые выше истории происходят из народного предания. Тезисы Трубачева были опубликованы неоднократно и на русском и на английском языках (Trubachev 1993) Несмотря на критику (Birnbaum 1988, 37-38) он придерживался к своему мнению до конца жизни (Трубачев 1998, 53-62). В статье 1998 г. у Трубачева рассказ «Нестора» упоминается как факт, согласно чему все славяне отправились от прародины на Дунае и так пришли на свое будущее место жительства (Трубачев 1998, 53-62).

Для Трубачева является неоспоримым авторитетом П. Й. Шафарик, чешский ученый XIX в. Все критические замечания, написанные о нем, о его деятельности, о его установлениях Трубачев отвергает как в произведениях с начала XX в. так и с современной литературы (Rostafiński 1908, 8-10; Beranová 1996). A результаты польской археологии по отношению к прародине славян, которые не поддерживают гипотезы Трубачова, отвергались им без всякой аргументации.

В сборнике статьей, опубликованном в 2002 г. и переизданном в 2003 г., повторяются взгляды Трубачева. Книга, кажется, вышла с целью итожить деятельность автора, как это отражается в ряде названий глав и подзаголовков. Нпр. Этногенез славян и индоевропейская проблема; Славянская и индоевро- 
пейская гидронимия; Славянская этимология и праславянская культура; Реконструкция древнейшей культуры и этногенез славян. Хотя в предисловии сформулировано: „Дунайская, иначе центрально-европейская теория локализации древнего ареала славян оснащается в книге новыми аргументами и соображениями.” (Трубачев 2002, 11), на самом деле содержит повторения бывших позиций.

Трубачев особенно отрицательно относится к выводам польских авторов, как нпр. языковеда Лешка Мошынского (Moszyński 1992.; мнение Трубачева см. Трубачев 2002, 414-431) и выше упомянутых археологов (см. Трубачев 2002, 7; Работы Годловского изданы Парчевским см. Godłowski 2000; Parczewski 1993). По Трубачеву в польской науке «кризис автохтонного аспекта» [sic!] (Трубачев 2002, 7), но он не пустится в дискуссию с установлениями польских ученых. Таким же способом Трубачев выражает свое несогласие в связи с исследованиями и результатами немецкого автора, Й. Удольфа (Udolph 1979; несогласие Трубачева 1998, 56-57).

Во главе Славяне и Дунай обширно говорится о разнообразности понятий «прародина» и «обретение / взятие родины» венграми, но при этом непонятно, как упомянутые понятия подкрепляют гипотезу Трубачева (Трубачев 2002, 14-15) о подунайской прародине славян. Русский языковед не обращает внимания на то, что оба понятия являются продуктами историографии XIX в. Он также не считает важными историческими фактами, как нпр. переселением народов на протяжении столетий, вследствие чего в Карпатском бассейне оказался ряд кочевых народов уже до появления венгров.

В гипотезе Трубачева находятся ошибки методического характера. Вопервых, в поиске прародины - не только славян, но и любого этноса - нельзя опираться на достижения лишь одной или другой науки, в данном случае на языкознание. Особенно важны результаты археологии, нпр. требует особого внимания связывать археологические культуры с этносом - и надо считать тем, что это в ряде случаев невозможно (Parczewski 1993, 121). И также нельзя упустить из виду аргументы, свидетельствующие о расселении славян, если они не совпадают с мнением автора. У Трубачева не упоминаются аргументы Годловского. (Godłowski 2000a, 107-169б впервые опубликовано в 1979 г.) Во-вторых, в том регионе, где жили славяне наблюдалось интенсивное движение народов, для реконструкции событий надо собирать данные всех возможных письменных источников. Во-третьих, при использовании летописного материала нельзя обойти достижений текстологии о происхождении текста, о заимствованиях из разных источников и т. д. В случае ПВЛ для Трубачева были бы под рукой достижения русской филологии начиная с А.А. Шахматова до Д.С. Лихачева и современных исследователей. Из значительных работ по летописанию уже давно ясно, что интерпретация летописных текстов невозможно без критического подхода, и надо обратить внимание на контекст, на заимствования и на компиляции. 
Спустя упомянутых аспектов и методологических требований Трубачев практически самовольно подобрал материал, сделал вид, как будто в литературе не было никаких противоречивых ему аргументов. Он поступает так не только в вопросах археологии и текстологии, но и в лингвистических вопросах. Использовав названия поселений Карпатского бассейна вовсе не обратил внимание на хронологию возникновения; а в случае названий вод на установление венгерского языковеда-слависта И. Кнежа: «Названия всех значительных рек Подунавья и Балкан (Дунай, Тиса, Самош, Кереш, Марош, Темеш, Раба, Драва, Сава, Босна, Кульпа, Нарента, Струна и т.д.) неславянского происхождения, а если бы в этом регионе лежала прародина славян, было бы непонятным.» (Kniezsa 2000, 13, репринт с 1942 г.).

Подведя итоги надо подчеркнуть, что гипотеза Трубачева не встречала согласия в науке. По данным археологии прародина славян была расположена на севере от Карпат, растянулась с верхнего течения Вислы на западе до среднего течения Днепра на востоке - как это доказывают данные археологии (Hensel 1984; Conte 1985, 47-63 (карта 48); Parczewski 1993, 119-138). Однако, Парчевски не дает определяющего значения названиям вод в локализации прародины (Parczewski 1993, 122; также на основе археологических данных Dolukhanov 1996, 160-167). Годловски (Godłowski 2000b, 346-348, 355) указал на то, что гипотеза Трубачева о прародине славян, в которой русский лингвист отвергает как критику письменных источников, так и результаты археологии, вытекает из его славофильских взглядов. Недавно к такому же мнению пришел Сергій Плохи по отношению к другим авторам (Plokhy 2006, 25-26). Припомним лишь некоторые из последних работ, касающихся древней истории славян: П. Штадлер писал об организации аваров в Карпатском бассейне, в которой доказано присутствие славян (Stadler 2008, 73); а Г. Сентэ об этнических отношениях Карпатского бассейна со степью (Szenthe 2016, 358-360). Среди монографий, в которых анализируются византийские источники с известиями о славянах, являются безусловно неизбежными книги Л. Вальдмюллера, Г. Подскальского, А. Авенариуса и Ф. Курты (Waldmüller 1975, 5-21; Podskalsky 1982, 56-72; Avenarius 2000, 20-22; Curta 2001). В современной русской историографии преобладает подход к данным вопросам, совпадающий с достижениями перечисленных авторов (Петрухин 2012, 11), однако в научно-популярной литературе все еще попадаются произведения, полны фантазией (Асов, Осташко и Васильев 2011; Алексеев 2016). 


\section{БИБЛИОГРАФИЯ}

\section{Источники}

Cosmas Pragensis = Cosmas von Prag. 1995, Die Chronik der Böhmen, hrsg. von B. Bretholz, München, Monumenta Germaniae Historica (Monumenta Germaniae Historica. Scriptores rerum Germanicarum, Nova Series 2).

Gallus Anonymus = Galli Anonymi, Cronicae et gesta ducum sive principum Polonorum 1952, C. Maleczyński (ed.), Cracoviae, Nakładem Polskiej Akademii Umiejętności (Monumenta Poloniae Historica, Nova Series 2).

Gall Névtelen = Gall Névtelen 2007, A lengyel fejedelmek avagy hercegek krónikája és tettei. D. Bagi (Fordította, bevezető tanulmánnyal és jegyzetekkel ellátta), Budapest, Argumentum.

Истрин 1971 = Хроника Георгия Амартола в древнем славянорусском переводе. В.М. Истрин (изд.), Петроград, Российская государственная академическая типография, 1922 (reprint: Die Chronik des Georgios Hamartolos, München, Fink, 1971).

[Istrin 1971 = Khronika Georgiiâ Amartola v drevnem slaviānorusskom perevode. V.M. Istrin (izd.), Petrograd, Rossiǐskaiā gosudarstvennaiā akademicheskaiā tipografiiā, 1922 (reprint: Die Chronik des Georgios Hamartolos, München, Fink, 1971).]

Истрин 1994 = Истрин В.М. 1994, Хроника Иоанна Малалы в славянском переводе, М.И. Чернышева (Подготовка, вступительная статья и комментарии), Москва, Джон Уайли энд Санз.

[Istrin 1994 = Istrin V. M. 1994, Khronika Ioanna Malaly v slavianskom perevode, M. I. Chernysheva (Podgotovka, vstupitel'naia stat'ia i kommentarii), Moskva, Dzhon Uařli end Sanz.]

ПВЛ = Повесть временных лет. 1950, т. 1. Текст и перевод, Д. С. Лихачев и Б. А. Романов (изд.), т. 2. Д. С. Лихачев, Примечания, статьи, комментарии, В.П. Адрианова-Перетц (ред.), МоскваЛенинград, Издательство Академии Наук СССР (переиздания: Санкт-Петербург 1999, 2007, с новыми комментариями 2012).

$\left[\mathrm{PVL}=\right.$ Povest $^{\prime}$ vremennykh let. 1950. T. 1. Tekst i perevod, D.S. Likhachev i B.A. Romanov (izd.). T. 2. D.S. Likhachev, Primechanniia, stat'i, kommentarii, V.P. Andrianova-Peretc (red.), Moskva-Leningrad, Izdatel'stvo Akademii Nauk SSSR (pereizdaniia: Sankt-Peterburg 199, 2007, s novymi kommentariiami 2012).]

ПСРЛ т. І. = Полное собрание русских летописей, т. І. Лаврентьевская летопись. 2001 изд. Б.М. Клосс, Москва, Языки славянской культуры.

[PSRL t. I. = Polnoe sobranie russkikh letopiseǐ. T. I. Lavrent'evskaîa letopis'. 2001 izd. B.M. Kloss, Moskva, Tazyki slavianskoĭ kul'tury.]

Régmúlt idők elbeszélése = Régmúlt idők elbeszélése. A Kijevi Rusz elsö krónikája, 2015, I. Ferincz (ford.), L. Balogh, I. Ferincz, M. Font, Sz. Kovács, Sz. Polgár, I. Zimonyi (A jegyzeteket írták) L. Balogh, I. Ferincz, M. Font, Sz. Kovács (A tanulmányokat írták), L. Balogh és Sz. Kovács (szerk.), Budapest, Balassi Kiadó (Magyar Östörténeti Könyvtár, 30).

Шахматов 1916 = Шахматов А.А. 1916, Повесть временных лет, Петроград, Издание Археографической комиссии.

[Shakhmatov 1916 = Shakmatov A.A. 1919, Povest' vremennykh let, Petrograd, Izdanie Arkheograficheskoř komissii.]

\section{Литература}

Алексеев 2016 = Алексеев С.В. 2016, Древняя история славян, Москва, Вече.

[Alekseev 2016 = Alekceev S.V. 2016, Drevniaia istoria slavian, Moskva, Veche.]

Асов, Осташко и Васильев 2011 = Асов А.И., Осташко А.В., Васильев А.В. 2011, Древние славяне.

Прародина, предки, святины, Москва, АСТ. 
[Asov, Ostashko i Vasil'ev 2011 = Asov A.I., Ostashko A.V., Vasil'ev A.V. 2011, Drevnie slaviane. Prarodina, predki, sviatiny, Moskva, AST.]

Avenarius 2000 = Avenarius A. 2000, Das byzantinische Kultur und die Slawen. Zum Problem der Rezeption und Transformation (6. bis 12. Jahrhundert), Wien, Oldenbourg Verlag.

Bagi 2007 = Bagi D. 2007, A lengyel fejedelmek avagy hercegek krónikája és tettei címü mü szerzöje és szövege, in: Gall Névtelen, 7-77.

Bagi 2012 = Bagi D. 2012, Sclavonia a Magyar - lengyel krónikában, in: „Köztes-Európa” vonzásában. Ünnepi tanulmányok Font Márta tiszteletére, D. Bagi, T. Fedeles és G. Kiss (szerk.), Pécs, Kronosz, 45-58.

Balogh 2015 = Balogh L. 2015, A magyarság a kelet-eirópai népek sorában, in: Régmúlt idők elbeszélése, 279-302.

Beranová 1996 = Beranová M. 1996, Šafařík a současná archeologie, „Slavia“ 65 (1), 99-102.

Birnbaum 1988 = Бирнбаум Х. 1988, Славянская прародина: новые гипотезы (с заметками по поводу происхождения индоеврейцев), „Ворпосы языкознания” 1988 (5), 35-49.

[Brinbaum 1988 = Brinbaum Kh. 1988, Slavianskaia prarodina: novye gipotezy (s zametkami po powodu proiskhozhdeniia isdoevrě̌cev), „Voprosy iazykoznaniia” 1988 (5), 35-49.]

Conte 1985 = Conte F. 1985, Les Slaves. Aux origines des civilisations d'Europe centrale et orientale (VI ${ }^{e}$-XIII ${ }^{e}$ siècles), Paris, Albin Michel.

Curta 2001 = Curta F. 2001, The Making of the Slavs 500-700, Cambridge, Cambridge University Press.

Dolukhanov 1996 = Dolukhanov P.M. 1996, The Early Slavs. Eastern Europe from the Initial Settlements to the Kievan Rus', London-New York, Longman.

Font 2003 = Фонт М. 2003, Первые хронисты и летописцы среднеевропейского средневековья, „Studia Slavica Academiae Scientiarum Hungariae” 48 (1-3), 71-80.

[Font 2003 = Font M. 2003, Pervye khronisty i letopiscy sredneevropeǐskogo srednevekov'ia, „Studia Slavica Academiae Scientiarum Hungariae" 48 (1-3), 71-80.]

Font $2010=$ Font M. 2010, A Povest'vremennych let szerkezete és hitelessége, in: M. Font, T. Fedeles, G. Kiss (szerk.), Aktualitások a magyar középkorkutatásban, Pécs, Történeti Segédtudományok Szeminárium, 307-325.

Font 2013 = Font M. 2013, Völker - Kultur - Beziehungen. Zur Entstehung der Regionen in der Mitte des mittelalterlichen Europa, Hamburg, Verlag Dr. Kovač.

Font 2015 = Font M. 2015, A Poveszty vremennih let mint történeti forrás, w: Régmúlt idők elbeszélése, 249-278.

Godłowski 2000 = Godłowski K. 2000, Pierwotne siedziby Słowian. Wybór pism, M. Parczewski (red.), Kraków, Instytut Archeologii Uniwersytetu Jagiellońskiego.

Godłowski $2000 \mathrm{a}=$ Godłowski K. 2000a, Z badań nad zagadnieniem rozprzestrzenienia Stowian $w$ V-VII w. n.e., w: Godłowski 2000, 107-169.

Godłowski 2000b = Godłowski K. 2000b, Spór o Stowian, w: Godłowski 2000, 345-369.

Hensel 1984 = Hensel W. 1984, Skąd przyszli Stowianie?, Wrocław, Wydawnictwo Stronnictwa Demokratycznego Epoka.

Kersken 1995 = Kersken N. 1995, Geschichtsschreibung in Europa der ,,nationes”. Nationalgeschichtliche Gesammtdarstellungen im Mittelalter, Münster, Böhlau Verlag (Münsterische historische Forschungen 8).

Kniezsa 1938 = Kniezsa I. 1938, Magyarország népei a XI. században, in: J. Serédi (szerk.), Emlékkönyv Szent István király halálának kilencszázadik évfordulóján 2, Budapest, A Magyar Tudományos Akadémia Kiadása, 367-472.

Kniezsa 2000 = Kniezsa I. 2000, A szlávok östörténete, in: Gy. Szekfü (szerk.), A magyarság és a szlávok. Niederhauser Emil utószavával. Budapest, Lúcidus Kiadó, 2000 (első kiadás: 1942), 9-35.

Kristó 2002 = Kristó Gy. 2002, Magyar historiografia, 1. Történetírás a középkori Magyarországon, Budapest, Osiris Kiadó.

Melich 1925-1929 = Melich J. 1925-1929, Honfoglaláskori Magyarország, Budapest, Magyar Tudományos Akadémia Kiadása.

Moór 1930 = Moór E. 1930, Die slawische Ortsnamen der Theissebene, "Zeitschrift für Ortsnamenforschung“ 6 (2), 3-37, 105-140. 
Moszyńskí 1992 = Moszyńskí L. 1992, Die Vorgeschichtliche Religion der Slaven im Lichte der slavischen Sprachwissenschaft, Köln-Weimar-Wien, Böhlau Verlag.

Obolensky 1999 = Obolensky D. 1999, A Bizánci Nemzetközösség, Budapest, Bizantinológiai Intézeti Alapítvány (Varia Byzantina 3).

Parczewski 1993 = Parczewski M. 1993, Die Anfänge der Frühslawischen Kultur in Polen, Wien, Österreichische Gesellschaft für Ur-und Frühgeschichte.

Петрухин 2012 = Петрухин В.Я. 2012, Древняя Русь: этнический аспект становления и развития государственности, в: Т.Ю. Красовицкая, В.А. Тишков (ред.), 1150 лет российской государственности. Этнический и религиозный факторы в формировании и эволючии российского государства, Москва, Новый хронограф, 9-59.

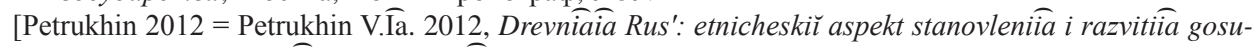
darstvennosti, v: T.Ju. Krasovickaîa, V.A. Tishkov (red.), 1150 let possiüskol gosudarstvennosti. Et-

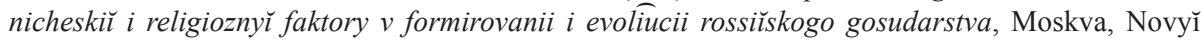
khronograf. 9-59.]

Plokhy 2006 = Plokhy S. 2006, The Origins of the Slavic Nations. Premodern Identities in Russia, Ukraine and Belarus, Cambridge, Cambridge University Press.

Podskalsky 1982 = Podskalsky G. 1982, Christentum und theologische Literatur in der Kiever Rus' (988-1237), München, C.H. Beck.

Rostafiński 1908 = Rostafiński J. 1908, O pierwotnych siedzibach $i$ gospodarstwie Słowian w przedhistorycznych czasach, Kraków, Nakładem Akademii Umiejętności.

Stadler 2008 = Stadler P. 2008, Avar Chronology Revisted, and the Question of Ethnicity in the Avar Quaganate, in: F. Curta (ed.), The Other Europe in the Middle Ages 450-1450. Avars, Bulgars, Khazars and Cumans, Leiden-Boston, Brill, 46-82.

Szenthe 2016 = Szenthe G. 2016, Crisis or Innovation? A Technology-inspired Narrative of Social Dynamics in the Carpathian Basin during the eighth Century, in: Á. Bollók, G. Csiky, T. Vida (ed.), Between Byzantium and the Steppe. Archeological and Historical Studies in Honour of Csanád Bálint on the Occassion of His $70^{\text {th }}$ Birthdy, Budapest, Institute of Archaeology, Research Centre for the Humanities, Hungarian Academy of Sciences, 351-370.

Thoroczkay 2016 = Thoroczkay G. 2016, A magyar krónikairodalom kezdeteiröl, in: Thoroczkay G., Ismeretlen Árpád-kor. Püspökök, legendák, krónikák, Budapest, L'Harmattan Kiadó, 103-114.

Tóth $2003=$ H. Tóth I. 2003, Cirill-Konstantin és Metód élete és müködése. Bevezetés a szláv kultúrtörténetbe, Szeged, József Attila Tudományegyetem. Bölcsészettudományi Kar és Szláv Filológiai Tanszék.

Трубачев 1982-1985 = Трубачев О.Н. 1982-1985, Языкознание и этногенез славян, „Вопросы языкознания" 1982 (4), 10-26, 1982 (5). 3-17, 1984 (2), 15-30, 1984 (3), 18-29, 1985 (4), 3-17, 1985 (5), 3-14.

[Trubachev 1982-1985 = Trubachev O.N. 1982-1985, Tazykoznanie $i$ etnogenez slavian, „Voprosy iazykoznaniia" 1982 (4), 10-26, 1982 (5). 3-17, 1984 (2), 15-30, 1984 (3), 18-29, 1985 (4), 3-17, 1985 (5), 3-14.]

Trubachev 1985 = Trubachev Oleg N. 1985, Linguistics and Ethnogenesis of the Slavs. The Ancient Slavs as evidenced by Etymology and Onomastics, ,Journal of Indo-European Studies” 13 (1-2), 203-256.

Trubachev 1993 = Trubachev O. 1993, The Ethnogenesis and Culture of the Ancient Slavs, „Palaeoslavica" $1,9-40$.

Трубачев 1998 = Трубачев О.Н. 1998, Взгляд на проблемы прародины славян (парадоксы науки и парадоксы жсизии), в: Ю.С. Кукушкин et alii (ред.), Культура славян и Русь. Сборник статей посвящен 90-летию Б.А. Рыбакова. Москва, Наука, 53-62.

[Trubachev 1998 = Trubachev O.N. 1998, Vzgliad na problemy prarodiny slavian (paradoksy nauki i paradoksy zhizni), v: Iu.S. Kukushkin et alii (red.), Kul'tura slavian u Rus'. Sbornik statě posviashchen 90-letiiu B.A. Rybakova. Moskva, Nauka, 53-62.]

Трубачев 2002 = Трубачев О.Н. 2002, Этногенез и культура древнейших славян. Лингвистические исследования, Москва, Наука (2003).

[Trubachev $2002=$ Trubachev O.N. 2002, Etnogenez i kul'tura drevneǐshikh slavian. Lingvisticheskie issledovaniia, Moskva, Nauka (2003).] 
Udolph 1979 = Udolph, J. 1979, Studien zur slawischen Gewässernamen und Gewässerbezeichnungen. Ein Beitrag zur Frage nach der Urheimat der Slawen, Heidelberg, Carl Winter Universitätsverlag 1979 (Beiträge zur Namenforschung. Neue Folge, Beiheft 17).

Waldmüller 1975 = Waldmüller L. 1975, Die ersten Begegnungen der Slawen mit dem Christentum und den christlichen Völkern vom VI. bis VIII. Jahrhundert. Die Slawen zwischen Byzanz und Abendland, Amsterdam, Adolf M. Hakkert (Enzyklopädie der Byzantinistik, Bd. 51). 